\title{
The Effect of Income on Democracy Revisited A Flexible Distributional Approach
}

\author{
Rajius Idzalika * $\quad$ Thomas Kneib $^{\dagger} \quad$ Inmaculada Martinez-Zarzoso ${ }^{\ddagger}$
}

8th October 2017

\begin{abstract}
We reexamine the effect of economic development on the level of democracy based on the data sets of Acemoglu et al. (2008) with a novel regression specification utilizing a zero-one-inflated beta distribution for the response variable democracy. Contrary to the results of Acemoglu et al. (2008), some support of a positive association between income and democracy is found when assuming that the variance of explanatory variables is heterogenous. In particular, our results show that rising income is associated with a higher probability of becoming fully democratic, but income is not generally associated with the mean level of democracy.
\end{abstract}

Keywords: income, democracy, beta distribution, bimodal, OECD.

Journal of Economic Literature Classification: O1, C16.

\footnotetext{
*Georg-August Universität Göttingen, Germany and the World Bank. Contact: ridzali@unigoettingen.de

${ }^{\dagger}$ Georg-August Universität Göttingen, Germany. Contact: tkneib@uni-goettingen.de

${ }^{\ddagger}$ Georg-August Universität Göttingen, Germany and University Jaume I, Spain. Contact: imartin@uni-goettingen.de.
} 


\section{Introduction}

The relationship between income and democracy has been widely investigated since the beginning of the twentieth century. While Acemoglu et al. (2008) already argued that there is a positive association between both factors more than twenty centuries ago, Lipset's law formalized it by stating that higher economic growth leads to a higher democracy level (Lipset, 1959). This law is (likely) the foundation of the modernization theory that asserts economic development as the major factor influencing the political environment. A number of authors, including Barro (1999), Dahl (1971), Huntington (1993) or Stephens et al. (1992), additionally contributed to the findings showing that higher incomes are associated with higher levels of democracy.

Nevertheless, recent empirical findings show a less clear story. Some support for a positive association between income and democracy is indeed found by Londregan and Poole (1996) when using panel data to estimate a causal relationship as stated by Lipset (1959) but only after considering leadership type and political context as control factors. Murtin and Wacziarg (2014) observe that the transition to democracy is linked to a fractional shift of illiterate to primary school graduates and, to a lesser extent, to income per capita. Moral-Benito and Bartolucci (2011) show instead a non-linear effect between income and democracy. Fayad et al. (2012) specifically distinguish between income from natural resources and other income. By applying heterogeneous panel techniques, the authors find that only when income comes from non resource sources is it significant in explaining democracy. Meanwhile, evidence of no causal relation has also been found by other authors. Przeworski et al. (2000) do not find any significant relationships between income per capita and transition to democracy when using a Markov transition model. This lack of evidence challenging Lipset's law is supported by Acemoglu et al. (2008) who use a panel data approach. Their study concludes that a causal effect from income to democracy cannot be found. However, a similar approach from Cervellati et al. (2014) reveals that the effect of income on democracy exists and it is heterogenous for former colonies and non-colonies.

One of the reasons why findings are inconclusive could be that the assumptions underlying the theoretical developments are inadequate. In this paper we assume that causality goes from economic performance to democracy. In this setting, an important issue is the choice of distributional assumption to approximate democracy when modelling its mean in a regression specification. In particular, most quantitative research assumes that the democracy variable is an unbounded continuous variable that has a homogenous variance which fits with the normal distribution implicitly assumed in least squares estimation. Nevertheless, democracy measurements are in general finite with the upper limit stated as "democratic" and the lower limit as "autocratic". Hence, the main novelty of this paper is to focus on the distributional assumption of democracy, which has not yet been investigated in the related literature.

We focus on the framework of Acemoglu et al. (2008) and contribute to the un- 
derstanding of this topic by evaluating the distributional assumption of democracy and its influence on the estimates. The main results indicate that when democracy is modeled with a zero-one-inflated beta regression (Ferrari and Cribari-Neto, 2004), higher incomes in the past increase the probability of a country being democratic. This finding is robust to changes in the data sources in most cases.

The paper is organized as follows. In Section 1 we briefly discuss why the research in this field generally comes to different conclusions and how this could be related to our primary concern, namely distributional assumptions that are questionable. Zero-one inflated beta distribution and regression are outlined in Section 2. We present our methodology in Section 3. The main results are presented in Section 4. Concluding remarks are given in Section 5.

\section{Distributional specification}

The recent empirical literature on the income democracy nexus has dealt with causality identification and omitted variable bias by using lags of the explanatory variables instead of levels in the right hand side. Additionally, country fixed effects are used to control for time-invariant unobserved heterogeneity (see for example Acemoglu et al. $(2008,2014)$ ). However, there are other issues, namely other sources of endogeneity, incomplete data, measurement error and the distributional assumption for the variable democracy, all of which have not been fully addressed or even ignored. In the related literature, some attention has been given to endogeneity, incomplete data and measurement error (Acemoglu et al. (2008); Moral-Benito and Bartolucci (2011); Treier and Jackman (2008)). Conversely, in this paper we focus on the latter to explore the zero-one inflated beta distribution as an alternative distributional assumption for democracy.

A parametric regression model relies on a specific distribution to derive the results. Assuming the normal distribution for the response variable given the explanatory variables is a handy approximation to fulfill the parametric assumption in the class of linear models. However, violations of this assumption makes any results questionable. Moreover, a bounded variable is by definition not normally distributed particularly when most observations are close to the boundaries. If this is the case, the variable of interest should not be used as a dependent variable in an ordinary least squares regression, which (at least implicitly) assumes normality for inference.

For illustration purposes, Table 1 reports summary statistics of the variables representing the level of democracy from the Freedom House Political Right Index and Polity IV data set as proxies for the level of democracy in a particular country ${ }^{1}$.

\footnotetext{
${ }^{1}$ Freedom House and Polity4 democracy variables are from Acemoglu et al. (2008). Among the various proxies of democracy that are available, we stick to Acemoglu et al. (2008) perspective by using their standardized indices from Freedom House and Polity IV for comparison purposes. The Freedom House index is based on a rating system ranging from 1 to 7 where smaller numbers represent a higher Freedom Rating. Polity IV is a multidimensional measure of political environment that is compressed into a scalar ranging from -10 to 10 . Positive numbers are in favor of democ-
} 
Table 1: Summary statistics of standardized democracy indices between 1960-2000, 211 countries

\begin{tabular}{cccccc}
\hline Variable & Observation & Trimmed mean (5\%) & St. Dev. & Min. & Max. \\
\hline Freedom House & 4732 & 0.49 & 0.38 & 0 & 1 \\
Polity IV & 5173 & 0.48 & 0.39 & 0 & 1 \\
\hline
\end{tabular}

Note: The trimmed mean is an aritmetic mean that discards sample at both tails of the distribution. Table 1 discards the lowest $5 \%$ and the highest $5 \%$ values.

The arithmetic mean is a natural characterization of the central tendency of a data set in particular for normally distributed variables.

Having the normality assumption in mind, the usual interpretation of a mean around 0.5 is that most of the countries are half democratic. The next step is to plot a histogram and a density estimate to examine whether these approximate something close to a bell-shape, which would indicate a normal distribution for the democracy variables.

Figure 1 illustrates that neither Freedom House nor Polity IV show such a bellshaped curve. Instead, their distributions are closer to a U-shaped curve with two peaks. As a consequence the unimodal interpretation no longer holds and the arithmetic mean does not represent the true central tendency, because it is a product of a compromise between two modes that center around zero and one. Therefore, it is the shape of the distributions and not the means that tell us something wellknown, which is that most of the countries are either highly democratic or highly autocratic. A few data points are in between, and some of them could be the countries in transition to democracy or to authoritarian regimes. If the conclusion is misleading for the arithmetic mean with the misspecified distribution, it will also be potentially misleading for the parameters of a regression model based on the misspecified distributional assumption.

An additional issue is that the values of democracy are bounded. Without considering this aspect when modeling the distribution of the data, the fitted values could lay outside the interval $[0,1]$. In this case, we should consider nonlinear models that take care of the nonlinearity and the bounded characteristics of the response variable.

It is important to take note of another prominent feature shown in Figure 2. In particular, the plot of the distributions indicates that the world is polarized into two clear political regimes. We visually tested whether the lower mode comes from non-OECD countries and the higher one depicts OECD countries by plotting the subset of OECD and non-OECD according to Freedom House and Polity IV in Figure $2^{2}$.

racy while negative numbers symbolize autocracy. Standardization transforms both scales into the identical range between zero and one.

${ }^{2}$ OECD refers to all members of OECD in 2014. Therefore, OECD is a loose term referring to the members of OECD during the sample period as well as its future members. 
Figure 1: Histogram and density plot of democracy between 1960-2000, 211 countries
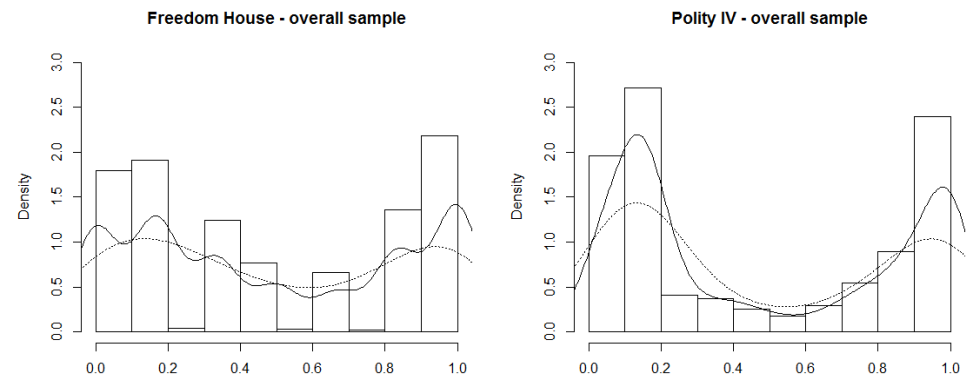

Note: The solid density lines have a smoothing bandwitdth of 1 and the dotted ones double the bandwidth.

Figure 2: Histogram and density plot of subsamples between 1960-2000, Freedom House (left) and Polity IV (right)
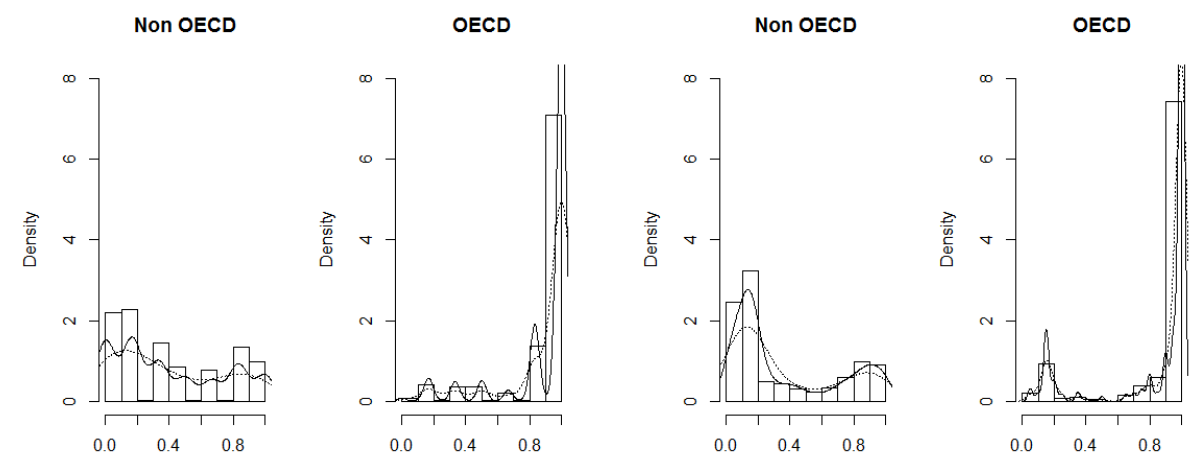

Note: The solid density lines have a smoothing bandwitdth of 1 and the dotted ones double the bandwidth.

The visual examination of Figure 2 suggests that the OECD group approximates the upper mode of the distribution, while the non-OECD subsample represents the lower mode. Moreover, the OECD group shows more variability. We anticipate that the high variation within the OECD sub-sample comes from the earlier period of the sample, seeing how nowadays all OECD countries are democratic. We will incorporate these features into the model to assess the statistical differences between both groups in the following parts.

\section{Zero-one-inflated beta distribution and regression}

A number of issues related to the suitable modeling strategy for bounded response variables have been discussed by Papke and Wooldridge (1996) under the heading of fractional response models. Possible extensions have also been recently summarized by Ramalho et al. (2011). The authors find that it is not reasonable to assume that the effect of explanatory variables is constant throughout the entire range of 
the response variable when the latter is bounded. They also argue that a beta distribution is not suitable for modelling bounded responses if values on the boundaries are observed with non-zero probability. However, while allowing for values on the boundaries, fractional response models only restrict the expectation of the response to the interval $(0,1)$ and not the complete distribution. Rather than using a fractional response specification, we therefore inflate the beta distribution with point masses in zero and one to account for the non-zero probability of observing these boundary values.

The mixed discrete-continuous density of a zero-one-inflated beta random variable is given by

$$
p(y)= \begin{cases}p_{0} & \text { if } y=0 \\ p_{1} & \text { if } y=1 \\ \left.\frac{1}{B(a, b)}\right) y^{a-1}(1-y)^{b-1} & \text { if } y \in(0,1)\end{cases}
$$

where $B(a, b)$ is the beta function with parameters $a$ and $b$ given by

$$
B(a, b)=\int_{0}^{1} y^{a-1}(1-y)^{b-1}
$$

where $a>0, b>0$.

The zero-one-inflated beta regression where the zero-one-inflated beta distribution is considered as the conditional distribution of the response was introduced by Ospina and Ferrari (2010). For the sake of interpretability, they propose a parameterization based on the expectation $\mu=\frac{a}{a+b}$ and the scale parameter vector $\sigma=\frac{1}{a+b+1}$ with $\mu \in(0,1)$ and $\sigma \in(0,1)$. They also replace the probabilities for zero and one by the parameters $v=p_{0} / p_{2}$ and $\tau=p_{1} / p_{2}$ where $p_{2}=1-p_{0}-p_{1}$ is the probability observing a response from the continuous part of the zero-oneinflated beta distribution. This parameterisation ensures that the probabilities for zero, one and the continuous part add up to one.

Furthermore, we let $y_{i t}$ be independent random variables where each $y_{i t}$ follows the density in (1) with mean $\mu_{i t}$, unknown scale parameter $\sigma_{i t}$ and zero/one inflation parameters $v_{i t}$ and $\tau_{i t}$, while $t=1, \ldots, T$ and $i=1, \ldots, N$ index the time dimension and the individuals, respectively. To relate the parameters of the zero one inflated beta distribution to regression predictors, we apply suitable link functions, i.e.

$$
\mu_{i t}=\frac{\exp \left(\eta_{i t}^{\mu}\right)}{1+\exp \left(\eta_{i t}^{\mu}\right)} \quad \sigma_{i t}=\frac{\exp \left(\eta_{i t}^{\sigma}\right)}{1+\exp \left(\eta_{i t}^{\sigma}\right)} \quad v_{i t}=\exp \left(\eta_{i t}^{v}\right) \quad \tau_{i t}=\exp \left(\eta_{i t}^{\tau}\right)
$$

where $\eta_{i t}^{\mu}, \eta_{i t}^{\sigma}, \eta_{i t}^{v}$ and $\eta_{i t}^{\tau}$ are regression predictors constructed from a set of covariates. The logit transformation applied to the mean and scale parameter enables a log odds ratio interpretation for two observations that only differ by one unit in the variable of interest. In contrast, the natural log transformation for the zero/one 
inflation parameters is directly interpretable since it is approximately proportional to differences ${ }^{3}$.

Note that the model allows us to account for heteroscedasticity due to the regression effects on $\sigma_{i t}$ and $\mu_{i t}$ since the variance of $y_{i t}$

$$
\operatorname{Var}\left(y_{i t}\right)=\frac{\mu_{i t}\left(1-\mu_{i t}\right)}{1+a_{i t}+b_{i t}}
$$

is also a function of the mean $\mu_{i t}$ and proportional to the scale parameter $\sigma_{i t}=$ $1 /\left(1+a_{i t}+b_{i t}\right)$.

Even though the approach by Papke and Wooldridge (1996) also does not exclude the boundary values, it is more suitable when the truly fractional component of the response is dominant. Conversely, the inflated beta regression better matches our data sets because we observe a large fraction of zeros and ones. Furthermore, the fully parametric approach used by assuming a beta distribution for the fractional response variable leads to more efficient ML estimators (Ospina and Ferrari, 2010).

\section{Model specification}

Our study estimates a similar model to Acemoglu et al. (2008) ${ }^{4}$. We use Maddison historical GDP per capita ${ }^{5}$ for a robustness check of measurement error and missing values. Hence, we have the combination of two democracy variables and two income per capita variables. We add a dummy variable for OECD membership, which acts as an additional regressor in each model. The OECD dummy is used as a parsimonious way to control for other factors that could impact democracy -besides income- and are also associated to economic development. Nevertheless, since being an OECD member is surely associated to income levels, in order to obtain also the full impact of income on democracy -and not only the partial impactthe model is also estimated withouth the OECD dummy. Moreover, another version of the model is estimated with the OECD dummy lagged several periods to avoid endogeneity issues.

We implement a linear model structure with fixed-effects under the assumption that the response follows the zero-one inflated beta distribution where the basic predictor structure is given by

$$
\eta_{i t}=\beta_{1} y_{i t-s}+\beta_{2} x_{1 i t-s}+\beta_{3} x_{2 i t}+\vartheta_{i}+\delta_{t}
$$

where $x_{1 i t-s}$ is $\log$ income per capita of country $i$ at time $t-s, x_{2 i t}$ is the OECD dummy of country $i$ at time $t, \vartheta_{i}$ is a country-specific fixed effect, $\delta_{t}$ is a timespecific fixed effect, and the predictor is linked to the parameters of the response

\footnotetext{
${ }^{3}$ The probabilities for the point masses in zero and one then could be estimated by the equations: $p_{0}=\frac{v}{1+v+\tau}, p_{1}=\frac{\tau}{1+v+\tau}$

${ }^{4}$ Linear model with country fixed-effects

${ }^{5}$ Maddison GDP per capita is from Bolt and van Zanden (2013) with authors' adjustment.
} 
distribution via the link functions discussed above. For the lagged part in the predictor, we used $s=1$ for yearly data ${ }^{6}, s=5$ for five year, $s=10$ for ten year and $s=20$ for twenty year data, respectively. We use five year averages of data $t=\overline{x_{5}}$ and their first lag in equation (2) to mitigate endogeneity. We also employ the lagged values of explanatory variables for the same purpose as well as to design the causality relationship. To fit zero-one-inflated beta regression models, we used the R-package gamlss (R Core Team (2016); Rigby and Stasinopoulos (2005); Stasinopoulos et al. (2008)).

Because the zero-one-inflated beta regression allows us to estimate not only the mean as a function of the explanatory variables but also the scale parameter, which is proportional to the variance, and the two probabilities for zero and one inflation, we can infer the causes of potential non-constant variance, as well as other distributional features of democracy at time $t$. Despite having a relatively suitable distributional assumption and some treatment for other statistical challenges, we do not claim that our estimation has a rigorous causal interpretation. Instead, our intention is to provide a benchmark for future related research.

\section{Results}

\subsection{Key findings}

The main results of our model for different time intervals are presented in Table 2. The first column shows the model estimated with five year data (model M1), the second to third with ten (M2), twenty year (M3) intervals data, and the last column is for five-year average data (M4). In each model, estimated coefficients are presented for the equation for $\mu$ which represents the mean of the beta distribution, the equation for $\sigma$ which relates to the scale parameter of the beta distribution and the equations for $v$ and $\tau$ which relate to the probabilities for zero and one inflation, respectively ${ }^{7}$.

The estimated coefficients for income per capita in the equation for $\mu$ are only significant in model (M2), in which a ten year interval and a ten year lag structure is used. In the equation for $\sigma$ income is significant in model (M1), (M4) and yearly data, suggesting that for annual, five year and five year average data, income influences the variance of democracy. The negative and significant income coefficient found for the five year, five year average and ten year lag in the equation for $v$ indicates that a higher income per capita level leads to a lower probability of a country having a value of zero (autocracy) than a value between zero and one in the next five and ten years. The evidence comes from the equation for $\tau$. The positive and significant coefficient of income (for five, ten, twenty year and five year average lags) suggests that a higher income induces a higher probability of a

\footnotetext{
${ }^{6}$ For $s=1$, we jointly estimate the coefficients of mean and scale parameters with the previous four lags.

${ }^{7}$ The result for yearly data are available on request.
} 
country having a value of one (democracy outcome) than a value between zero and one $^{8}$.

The OECD dummy is also significant in the equations for $\mu$ and $\sigma$ in some cases. The positive sign in the equation for $\mu$ reflects the higher level of democracy on average for OECD members relative to non-OECDs. Meanwhile, the positive sign in the equation for $\sigma$ indicates that the OECD group has a higher variance. This confirms the findings in Figure 2. The diagnostic plots for ten year intervals are provided in Figure 3.

As a comparison, we provide results for the Polity IV data in Table $3^{9}$. Table 3 suggests that our findings are not robust for the equations for $\mu$ and $v$, yet it is more robust for the equations for $\sigma$ and $\tau$. Past income explains the non-constant variance of democracy through the equation for $\sigma$ and the probability of being democratic is consistently significant through the equation $\tau$. Further, the latter evidence from $\tau$ also indicates that in most cases rising income is significantly associated with the probability of a country to achieve complete democratization, whereas decreasing income is only in a few cases associated with the probability of a country becoming fully autocratic. This fact indicates the existence of an asymmetry in the way countries move along the "degree of democracy" line.

The difference between the OECD and non-OECD groups is less apparent here. The dummy for OECD countries is significant and positive in the equation for $\mu$ in only two cases. The OECD dummy is also positive and statistically significant in the equation for $\tau$ in one case.

\footnotetext{
${ }^{8}$ Yearly data shows mixed signs.

${ }^{9}$ see Table A1 and A2 in the Appendix for the results obtained using other data set combinations.
} 
Table 2: Freedom House and Penn World Table GDP per capita

\begin{tabular}{|c|c|c|c|c|}
\hline $\begin{array}{c}\text { Dependent variable: } \\
\text { democracy }\end{array}$ & $\begin{array}{l}5 \text { year } \\
\text { (M1) }\end{array}$ & $\begin{array}{l}10 \text { year } \\
(\mathrm{M} 2)\end{array}$ & $\begin{array}{c}20 \text { year } \\
\text { (M3) }\end{array}$ & $\begin{array}{c}5 \text { year average } \\
\text { (M4) }\end{array}$ \\
\hline \multicolumn{5}{|l|}{ Mean equation $(\mu)$} \\
\hline Lag democracy & $\begin{array}{c}0.975 * * * \\
(0.184)\end{array}$ & $\begin{array}{c}-0.857 * * * \\
(0.277)\end{array}$ & $\begin{array}{c}-2.301 * * * \\
(0.346)\end{array}$ & $\begin{array}{c}2.368 * * * \\
(0.214)\end{array}$ \\
\hline Lag log income per capita & $\begin{array}{c}-0.028 \\
(0.161)\end{array}$ & $\begin{array}{c}0.574 * * \\
(0.285)\end{array}$ & $\begin{array}{l}-0.411 \\
(0.505)\end{array}$ & $\begin{array}{l}-0.021 \\
(0.162)\end{array}$ \\
\hline $\mathrm{OECD}(\mathrm{D})$ & $\begin{array}{c}2.180^{* *} \\
(0.980)\end{array}$ & $\begin{array}{c}2.251 * * * \\
(0.677)\end{array}$ & $\begin{array}{c}0.195 \\
(0.728)\end{array}$ & $\begin{array}{c}1.865^{* *} \\
(0.914)\end{array}$ \\
\hline Country fe & Yes & Yes & Yes & Yes \\
\hline Year fe & Yes & Yes & Yes & Yes \\
\hline \multicolumn{5}{|l|}{ Scale equation $(\sigma)$} \\
\hline Lag Democracy & $-* * *$ & + & No & $-* * *$ \\
\hline Lag log income per capita & + & - & No & + \\
\hline $\mathrm{OECD}(\mathrm{D})$ & $+*$ & $+* * *$ & No & + \\
\hline Country fe & No & No & No & No \\
\hline Year fe & No & No & No & No \\
\hline \multicolumn{5}{|l|}{ Zero inflation equation $(v)$} \\
\hline Lag democracy & $\begin{array}{c}-4.531 * * * \\
(0.681)\end{array}$ & $\begin{array}{c}-2.155^{* *} \\
(0.884)\end{array}$ & $\begin{array}{l}-1.284 \\
(1.658)\end{array}$ & $\begin{array}{c}-6.547 * * * \\
(0.947)\end{array}$ \\
\hline Lag log income per capita & $\begin{array}{c}-0.454 * * \\
(0.193)\end{array}$ & $\begin{array}{l}-0.647 * \\
(0.329)\end{array}$ & $\begin{array}{l}-0.974 \\
(0.770)\end{array}$ & $\begin{array}{l}-0414 * \\
(0.217)\end{array}$ \\
\hline $\mathrm{OECD}(\mathrm{D})$ & $\begin{array}{l}-1.449 \\
(1.057)\end{array}$ & $\begin{array}{c}-19.751 \\
(8.611 e+3)\end{array}$ & $\begin{array}{c}-13.344 \\
(776.982)\end{array}$ & $\begin{array}{l}-0.974 \\
(1.109)\end{array}$ \\
\hline Country fe & No & No & No & No \\
\hline Year fe & No & No & No & No \\
\hline \multicolumn{5}{|l|}{ One inflation equation $(\tau)$} \\
\hline Lag democracy & $\begin{array}{c}12.551 * * * \\
(1.932)\end{array}$ & $\begin{array}{c}5.321 * * * \\
(1.241)\end{array}$ & $\begin{array}{c}1.138 \\
(1.119)\end{array}$ & $\begin{array}{c}19.202 * * * \\
(2.974)\end{array}$ \\
\hline Lag log income per capita & $\begin{array}{c}2.893^{* * *} \\
(0.450)\end{array}$ & $\begin{array}{c}3.541 * * * \\
(0.641)\end{array}$ & $\begin{array}{c}4.046^{* * *} \\
(0.933)\end{array}$ & $\begin{array}{c}3.175^{* * * *} \\
(0.558)\end{array}$ \\
\hline $\mathrm{OECD}(\mathrm{D})$ & $\begin{array}{l}-0.755 \\
(0.473)\end{array}$ & $\begin{array}{l}-0.373 \\
(0.591)\end{array}$ & $\begin{array}{c}0.682 \\
(0.726)\end{array}$ & $\begin{array}{c}-1.517 * * \\
(0.596)\end{array}$ \\
\hline Country fe & No & No & No & No \\
\hline Year fe & No & No & No & No \\
\hline Observation & 729 & 317 & 112 & 639 \\
\hline Country & 117 & 106 & 69 & 118 \\
\hline Global deviance & 84.527 & 9.895 & -82.432 & -117.297 \\
\hline AIC & 364.527 & 259.895 & 83.568 & 162.704 \\
\hline SBC & 1007.362 & 729.757 & 309.203 & 787.090 \\
\hline
\end{tabular}

The coefficients are in logit form for the equations for $\mu$ and $\sigma$, in $\log$ form for the equations for $v$ and $\tau$. The equation for $\sigma$ only shows the direction of relationship and its significance level. Significance levels are $0.1(*)$, 0.05 (**) and 0.01 (***). Standard errors are in parentheses with "qr" type, which assumes there is no correlation among the parameters. Models M1-M3 are estimated using 5, 10 and 20 year intervals, respectively. 
Table 3: Polity IV and Penn World Table GDP per capita

\begin{tabular}{|c|c|c|c|c|}
\hline $\begin{array}{c}\text { Dependent variable: } \\
\text { democracy }\end{array}$ & $\begin{array}{l}5 \text { year } \\
\text { (M1) }\end{array}$ & $\begin{array}{c}10 \text { year } \\
\text { (M2) }\end{array}$ & $\begin{array}{c}20 \text { year } \\
\text { (M3) }\end{array}$ & $\begin{array}{c}5 \text { year average } \\
\text { (M4) }\end{array}$ \\
\hline \multicolumn{5}{|l|}{ Mean equation $(\mu)$} \\
\hline \multirow[t]{2}{*}{ Lag democracy } & $1.231 * * *$ & $-0.647 * *$ & $-3.826 * * *$ & $2.733 * * *$ \\
\hline & $(0.192)$ & $(0.321)$ & $(0.477)$ & $(0.218)$ \\
\hline \multirow[t]{2}{*}{ Lag log income per capita } & 0.070 & 0.086 & -0.261 & 0.073 \\
\hline & $(0.169)$ & $(0.315)$ & $(0.684)$ & $(0.171)$ \\
\hline \multirow[t]{2}{*}{ OECD (D) } & $2.058 * * *$ & 1.148 & 0.061 & $1.268^{*}$ \\
\hline & $(0.720)$ & $(0.728)$ & $(0.693)$ & $(0.670)$ \\
\hline Country fe & Yes & Yes & Yes & Yes \\
\hline Year fe & Yes & Yes & Yes & Yes \\
\hline \multicolumn{5}{|l|}{ Scale equation $(\sigma)$} \\
\hline Lag democracy & - & $+^{*}$ & $+* * *$ & $+* *$ \\
\hline Lag log income per capita & + & - & $-* * *$ & - \\
\hline $\mathrm{OECD}(\mathrm{D})$ & - & $+* *$ & - & - \\
\hline Country fe & No & No & No & No \\
\hline Year fe & No & No & No & No \\
\hline \multicolumn{5}{|l|}{ Zero inflation equation $(v)$} \\
\hline \multirow[t]{2}{*}{ Lag democracy } & $-75.706^{* * *}$ & $-56.984 *$ & $5.647 \mathrm{e}-7$ & $-93.691 * * *$ \\
\hline & (20.593) & $(29.492)$ & $(1.607 e+6)$ & $(31.673)$ \\
\hline \multirow[t]{2}{*}{ Lag log income per capita } & 0.456 & 0.471 & $1.119 \mathrm{e}-7$ & 1.353 \\
\hline & $(0.724)$ & $(1.050)$ & $(7.855 e+5)$ & $(1.163)$ \\
\hline \multirow[t]{2}{*}{ OECD (D) } & -12.883 & -13.066 & $3.395 \mathrm{e}-7$ & -12.773 \\
\hline & $(1.331 \mathrm{e}+3)$ & $(1.367 \mathrm{e}+3)$ & $(1.506 \mathrm{e}+6)$ & $(2070.862)$ \\
\hline Country fe & No & No & No & No \\
\hline \multirow{2}{*}{$\begin{array}{c}\text { Year fe } \\
\text { One inflation equation }(\tau)\end{array}$} & No & No & No & No \\
\hline & & & & \\
\hline \multirow[t]{2}{*}{ Lag democracy } & $35.099 * * *$ & $7.100 * * *$ & $4.541 * * *$ & $41.937 * * *$ \\
\hline & (5.086) & $(2.075)$ & $(1.509)$ & (6.358) \\
\hline \multirow[t]{2}{*}{ Lag log income per capita } & $1.338 * * *$ & $2.280 * * *$ & $2.335 * *$ & $1.222 * *$ \\
\hline & $(0.441)$ & $(0.574)$ & (1.009) & $(0.492)$ \\
\hline \multirow[t]{2}{*}{ OECD (D) } & 0.687 & 0.808 & $1.907 * *$ & 0.709 \\
\hline & $(0.538)$ & $(0.583)$ & $(0.924)$ & $(0.608)$ \\
\hline \multirow{2}{*}{$\begin{array}{l}\text { Country fe } \\
\text { Year fe }\end{array}$} & No & No & No & No \\
\hline & No & No & No & No \\
\hline Observation & 729 & 317 & 112 & 639 \\
\hline Country & 118 & 106 & 69 & 119 \\
\hline Global deviance & -446.343 & -148.281 & -195.667 & -523.083 \\
\hline AIC & -164.343 & 101.719 & 23.667 & -241.083 \\
\hline SBC & 483.083 & 571.582 & 210.124 & 387.764 \\
\hline
\end{tabular}

The coefficients are in logit form for the equations for $\mu$ and $\sigma$, in $\log$ form for the equations for $v$ and $\tau$. The equation for $\sigma$ only shows the direction of relationship and its significance level. Significance levels are $0.1(*)$, $0.05(* *)$ and $0.01(* * *)$. Standard errors are in parentheses with "qr" type, which assumes there is no correlation among the parameters. Models M1-M3 are estimated using 5, 10 and 20 year intervals, respectively. 
Results for the overall sample from the two alternative data sets generally indicate a similar effect of lag income for the equations for $\sigma$ and $\tau^{10}$. Additionally, the sets were and to a large extent robust for the OECD dummy in the equations for $\mu$ and $\sigma$. Nevertheless, a detailed examination suggests that there is a sort of selection bias. The differences in results mainly depend on which income variable is used in the model. On the one hand, when using income data from the Penn World Table, a positive association between income and democracy is found more often than when using income data from Maddison. On the other hand, Maddison GDP favors significance for the OECD dummy. Hence, we conclude that even though the democracy indices are subject to measurement error, in our model specification they are more robust than the income per capita variables ${ }^{11}$.

Table 4: Freedom House and Penn World Table GDP per capita for sub samples

\begin{tabular}{|c|c|c|c|c|c|c|}
\hline \multirow{2}{*}{$\begin{array}{l}\text { Dependent } \\
\text { variable: } \\
\text { democracy }\end{array}$} & \multicolumn{2}{|c|}{5 year } & \multicolumn{2}{|c|}{10 year } & \multicolumn{2}{|c|}{5 year average } \\
\hline & $\begin{array}{l}\text { OECD } \\
\text { (M1) }\end{array}$ & $\begin{array}{c}\text { non-OECD } \\
\text { (M2) }\end{array}$ & $\begin{array}{l}\text { OECD } \\
\text { (M3) }\end{array}$ & $\begin{array}{c}\text { non-OECD } \\
\text { (M4) }\end{array}$ & $\begin{array}{l}\text { OECD } \\
\text { (M5) }\end{array}$ & $\begin{array}{c}\text { non-OECD } \\
\text { (M6) }\end{array}$ \\
\hline \multicolumn{7}{|l|}{ Mean equation $(\mu)$} \\
\hline Lag democracy & $\begin{array}{l}1.100^{*} \\
(0.620)\end{array}$ & $\begin{array}{c}0.891 * * * \\
(0.193)\end{array}$ & $\begin{array}{c}-2.651 * * * \\
(0.733)\end{array}$ & $\begin{array}{l}-0.583 * \\
(0.297)\end{array}$ & $\begin{array}{c}2.980 * * * * \\
(0.733)\end{array}$ & $\begin{array}{c}2.226 * * * * \\
(0.223)\end{array}$ \\
\hline Lag log income per capita & $\begin{array}{c}0.743 \\
(0.605)\end{array}$ & $\begin{array}{l}-0.152 \\
(0.174)\end{array}$ & $\begin{array}{c}2.104 * * * \\
(0.851)\end{array}$ & $\begin{array}{l}0.246 \\
(0.314)\end{array}$ & $\begin{array}{l}-0.212 \\
(0.597)\end{array}$ & $\begin{array}{l}-0.286 \\
(0.179)\end{array}$ \\
\hline Country fe & No & Yes & Yes & Yes & Yes & Yes \\
\hline Year fe & Yes & Yes & Yes & Yes & Yes & Yes \\
\hline \multicolumn{7}{|l|}{ Scale equation $(\sigma)$} \\
\hline Lag democracy & No & _** & No & + & No & -* \\
\hline Lag log income per capita & -*** & + & - & + & $-* * *$ & + \\
\hline Country fe & No & No & No & No & No & No \\
\hline Year fe & No & No & No & No & No & No \\
\hline \multicolumn{7}{|l|}{ Zero inflation equation $(v)$} \\
\hline Lag democracy & $\begin{array}{c}2049.948 \\
(3.742 \mathrm{e}+6)\end{array}$ & $\begin{array}{c}-4.895^{* * * *} \\
(0.721)\end{array}$ & $\begin{array}{c}1.267 e-6 \\
(1.787 e+4)\end{array}$ & $\begin{array}{c}-2.169 * * * \\
(0.882)\end{array}$ & $\begin{array}{c}23.789 \\
(18.066)\end{array}$ & $\begin{array}{c}-7.296 * * * \\
(1.038)\end{array}$ \\
\hline Lag log income per capita & $\begin{array}{l}-4.036 \\
(3.564)\end{array}$ & $\begin{array}{c}-0.426^{* * *} \\
(0.195)\end{array}$ & $\begin{array}{c}5.165 \mathrm{e}-7 \\
(1.221 \mathrm{e}+4)\end{array}$ & $\begin{array}{c}-0.636^{*} \\
(0.331)\end{array}$ & $\begin{array}{l}-7.258 \\
(6.924)\end{array}$ & $\begin{array}{l}-0.369 * \\
(0.220)\end{array}$ \\
\hline Country fe & No & No & No & No & No & No \\
\hline Year fe & No & No & No & No & No & No \\
\hline \multicolumn{7}{|l|}{ One inflation equation $(\tau)$} \\
\hline Lag democracy & $\begin{array}{c}19.484 * * * \\
(3.672)\end{array}$ & $\begin{array}{c}9.506 * * * \\
(1.950)\end{array}$ & $\begin{array}{c}20.212^{* * *} \\
(7.028)\end{array}$ & $\begin{array}{c}3.405^{* * * *} \\
(1.264)\end{array}$ & $\begin{array}{c}23.938^{* * * *} \\
(4.979)\end{array}$ & $\begin{array}{c}16.300^{* * * *} \\
(3.466)\end{array}$ \\
\hline Lag log income per capita & $\begin{array}{c}3.337 * * * \\
(0.747)\end{array}$ & $\begin{array}{c}2.406 * * * * \\
(0.553)\end{array}$ & $\begin{array}{c}4.615 * * * \\
(1.047)\end{array}$ & $\begin{array}{c}2.989 * * * \\
0.758\end{array}$ & $\begin{array}{c}3.764 * * * * \\
(0.894)\end{array}$ & $\begin{array}{c}2.579 * * * \\
(0.723)\end{array}$ \\
\hline Country fe & No & No & No & No & No & No \\
\hline Year fe & No & No & No & No & No & No \\
\hline Observation & 216 & 513 & 109 & 208 & 190 & 449 \\
\hline Country & 28 & 101 & 27 & 78 & 28 & 89 \\
\hline Global deviance & -14.618 & 40.620 & -17.550 & -10.418 & -50.171 & -129.081 \\
\hline AIC & 77.382 & 254.620 & 64.450 & 175.582 & 39.829 & 84.919 \\
\hline SBC & 232.644 & 708.330 & 174.795 & 485.974 & 185.945 & 524.370 \\
\hline
\end{tabular}

The coefficients are in logit form for the equations for $\mu$ and $\sigma$, in $\log$ form for the equations for $v$ and $\tau$. The equation for $\sigma$ only shows the direction of relationship and its significance level. Significance levels are $0.1(*)$, $0.05(* *)$ and $0.01(* * *)$. Standard errors are in parentheses with "qr" type, which assumes there is no correlation among the parameters. Models M1-M3 are estimated using 5, 10 and 20 year intervals, respectively. Country fixed-effects and year fixed-effects are used only when the algorithms converge.

Our further estimation for the OECD versus non-OECD subsamples (see Table 4) shows that the positive association between income and democracy is only statistically significant in the OECD countries. Whereas, the probability is significant for both subsamples. However, there is no evidence of positive association

\footnotetext{
${ }^{10}$ Results are robust to OECD dummy exclusion and are available on request.

${ }^{11}$ Results are robust to restricted samples where countries data sets are available in all four sources.
} 
between OECD membership history and democracy ${ }^{12}$

${ }^{12}$ see Table A3 in the Appendix. 
Figure 3: Diagnostic plots for ten year intervals: overall sample (top panel) and OECD (bottom panel)
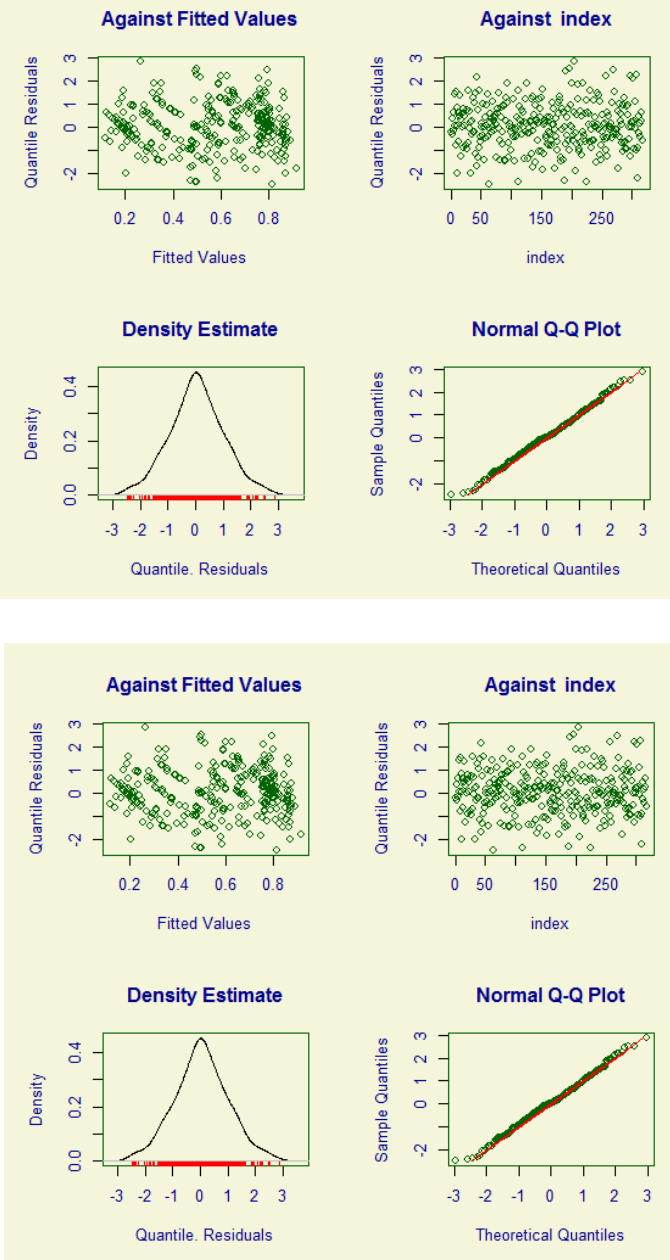

Against Fitted Values
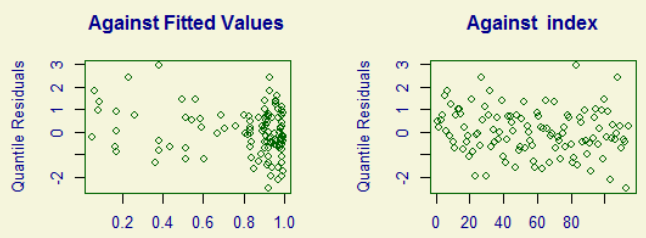

Fitted Values

index

Density Estimate

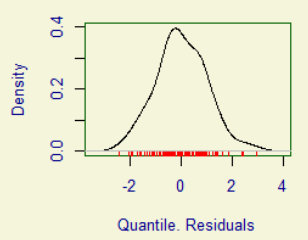

Normal Q-Q Plot

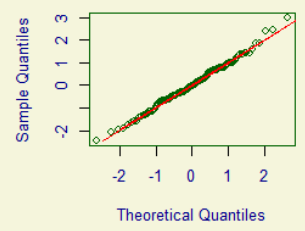




\subsection{Discussion of the results}

In this sub-section we provide specific examples that will allow us to help with inference and with the interpretation of the sizes of the coefficients provided in the main table of results (Table 2).

Firstly, in order to infer to what extent a higher level of income increases the level of democracy we make use of a predictive analysis. Two countries with an identical level of democracy but different level of income are selected. Those are India, which represents lower middle income countries, and Brazil, which represents upper middle income countries. In 2000, both appeared to be at the upper level of democracy, but never committed to be completely democratic.

Figure 4 shows the predicted probabilities of being fully democratic, given the top five deciles of income for the whole sample. It suggests that provided with the artificial higher levels of lag income, Brazil is more likely to become fully democratic than India. The results using five year interval data, five year average data, ten year interval data and twenty year interval data of Brazil are in favor of full democracy in Brazil when the income drastically increases, i.e. at least in percentile $80 \%$. Meanwhile, India's fully democratization is only supported by two data sets ${ }^{13}$. In fact, the original levels of income (see Table A4 in the Appendix) could not boost the likelihood of becoming fully democratic. The probabilities for Brazil never exceed more than 0.5 , while the chance for India is virtually zero. The income differences between Brazil and India, also that the predicted probabilities for full democracy increase when using the high level of artificial income, indicates that income is an important factor in determining the probability to reach a fully democratic regime.

Secondly, by examining the data we observe that the number of countries that were never fully democratic or fully autocratic is 53 countries (122 countries) when the democracy proxy comes from Freedom House (Polity IV) (see Table A7 in the Appendix for the list of countries). These figures represent 31\% (72\%) of the total number of countries in each sample. The size suggests that there is a moderate fraction of countries according to the first source (a large fraction -according to the second-) -that have always been partially democratic during the period analyzed.

The pattern of democracy path over time is provided in Figure 5. The results using both sources (Freedom House in the left side of Figure 5 and Polity IV in the right side) consistently support a similar story, for instance, there is no sign of mean reversion for countries that were partially democratic. Instead, after a sharp decrease in the early 1970s, there is a gradually upward trend from a lower baseline to a more democratic regime on average. In particular, the transition seems to be slower for Freedom House than for Polity IV, especially in the period from 1990 to 2000. Our estimations are in line with this visualization, indicating that there is a good opportunity for countries in transition to become fully democratic because they do not appear to get persistently trapped in the middle level of the democracy

\footnotetext{
${ }^{13}$ The predicted estimation for complete democracy using $80 \%, 90 \%$ and $100 \%$ percentiles is provided in Table A5 and A6 in the Appendix.
} 
Figure 4: Predicted probabilities for complete democratization: India and Brazil in 2000

India

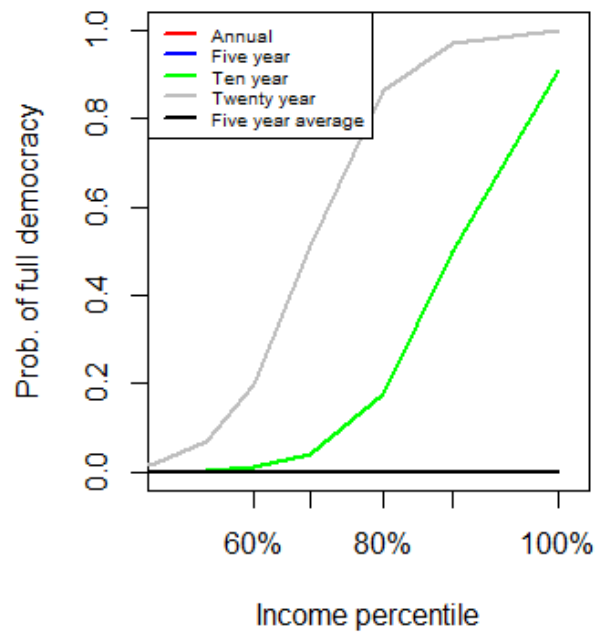

Brazil

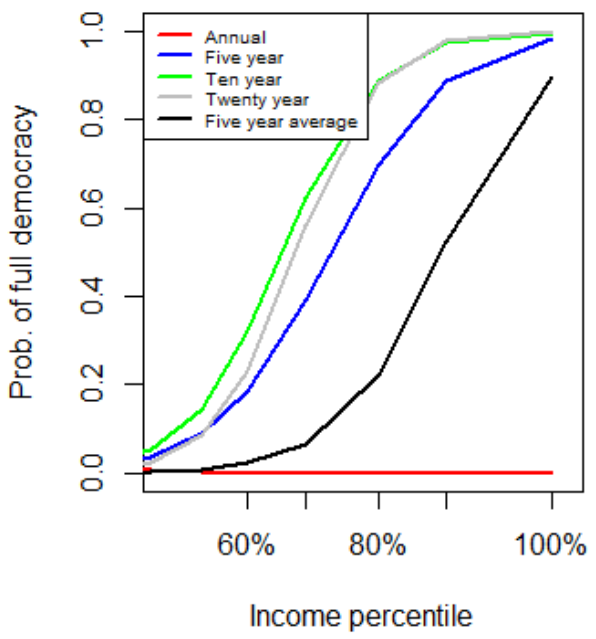

Note: Annual, five year and five year average lines for India overlap each other.

score.

\section{Concluding remarks}

Which comes first, income or democracy? The chicken and egg causality dilemma reflects the existence of opposite theoretical perspectives in which empirical evidence has been found to support each side. Inconclusive findings together with statistical challenges have converted the study of the relationship into a far more complex issue than what Aristotle proposed a long time ago. Among the acknowledged statistical issues, we claim that the usual distributional assumption for democracy as a response variable could be inappropriate. In particular, the use of an unbounded distribution - such as a normal distribution - for a bounded variable that has dominant observations around the boundaries of its domain could cause problems. Furthermore, the conclusions derived from an analysis that rely on the wrong underlying assumptions could be misleading.

Although we find almost no support for income causing democracy when modelling the mean of democracy, we find that heteroscedasticity is an issue and that higher lag income increases the probability of a country being democratic. As the baseline evidence shows, we only find partial support for a positive correlation between income and democracy when modeling the mean of democracy with data every ten years and using income from the Penn World Table and democracy 
Figure 5: Democracy path of countries in transition towards democracy

Freedom House

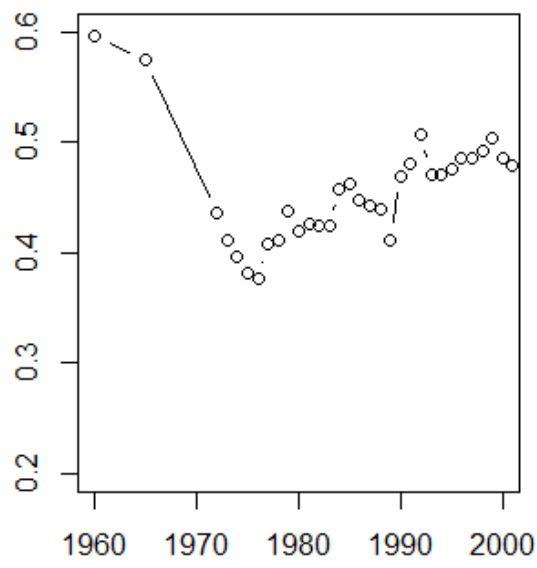

Polity IV

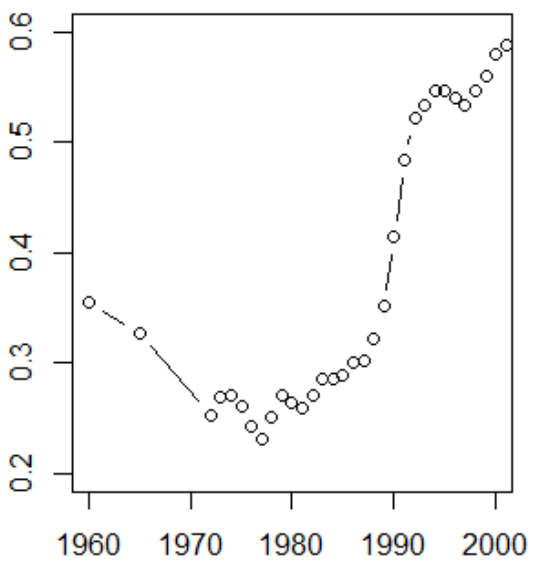

Note: Calculated based on the average democracy level of the target countries for each democracy data source. These arithmetic means are more representative since countries with extreme values $(0,1)$ are excluded.

from Freedom House. We acknowledge the fact that we do not address endogeneity issues in the way is usually done in the literature (using instrumental variables approaches). Hence, we should not strictly talk about causality, but correlation.

We also find systematic differences between OECD and non-OECD samples in the mean, variance and probabilities of zero and one inflation. OECD countries are on average more democratic and evidence that higher income is positively associated with higher democracy is only present for this group. This finding support the literature that the relationship between income and democracy is heterogenous. Moreover, we find that using Maddison GDP, being an OECD member increases the probability of being completely democratic while this is not the case when using Penn World Table data for income. The differences encountered when using Penn World Table and Maddison data indicate that economic measurement seems to matter and can influence the inferences that we draw. A caveat of our approach is that we are unable to address the potential existence of a selection bias, since countries accession to the OECD is partly based on their income per capita. We leave this issue for further research.

Rajius Idzalika acknowledges the financial support from the European Commission. This publication reflects the views of the authors, and the Commission cannot be held responsible for any use which may be made of the information contained therein. The authors are grateful to the anonymous referee of this journal for their constructive comments and 
also to Jennifer Phillips for proof-reading this article. 


\section{References}

Acemoglu, D., Johnson, S., Robinson, J. A., and Yared, P. (2008). Income and Democracy. American Economic Review, 98(3): 808-842.

Acemoglu, D., Naidu, S., Restrepo, P., and Robinson, J. A. (2014). Democracy Does Cause Growth. NBER Working Paper, (20004).

Barro, R. J. (1999). Determinants of Democracy. Journal of Political Economy, 107(S6). DOI 10.1086/250107.

Bolt, J., and van Zanden, J. L. (2013). The First Update of the Maddison Project: Re-Estimating Growth Before 1820. Maddison-Project Working Paper WP-4.

Cervellati, M., Jung, F., Sunde, U., and Vischer, T. (2014). Income and Democracy: Comment. American Economic Review, 104(2): 707-719.

Dahl, R. A. (1971). Polyarchy: Participation and Opposition. Yale University Press.

Fayad, G., Bates, R. H., and Hoeffler, A. (2012). Income and Democracy : Lipset's Law Revisited. IMF Working Paper, (12/295).

Ferrari, S. L., and Cribari-Neto, F. (2004). Beta Regression for Modelling Rates and Proportion. Journal of Applied Statistics, 31(7): 799-815.

Huntington, S. P. (1993). The Third Wave: Democratization in the Late Twentieth Century. University of Oklahoma Press.

Lipset, S. M. (1959). Some Social Requisites of Democracy: Economic Development and Political Legitimacy. The American Political Science Review, 53(1): 69-105.

Londregan, J. B., and Poole, K. T. (1996). Does High Income Promote Democracy? World Politics, 49(1): 1-30.

Moral-Benito, E., and Bartolucci, C. (2011). Income and Democracy: Revisiting the Evidence. Banco de Espana Working Paper, (1115).

Murtin, F., and Wacziarg, R. (2014). The democratic transition. J Econ Growth, 19: 141-181. DOI 10.1007/s10887-013-9100-6.

Ospina, R., and Ferrari, S. L. P. (2010). Inflated Beta Distribution. Stat papers, 51: 111-126.

Papke, L. E., and Wooldridge, J. M. (1996). Econometric Method for Fractional Response VVariable With an Application to 401 (K) Plan Participation Rates. Journal of Applied Econometrics, 11. 
Przeworski, A., Alvarez, M. E., Cheibub, J. A., and Limongi, F. (2000). Democracy and Development: Political Institutions and Well-Being in the World, 1950-1990. Cambridge University Press.

R Core Team (2016). $\quad R:$ A Language and Environment for Statistical Computing. R Foundation for Statistical Computing, Vienna, Austria. URL https://www.R-project.org.

Ramalho, E. A., Ramalho, J. J., and Murteira, J. M. (2011). Alternative Estimating and Testing Empirical Strategies for Fractional Regression Models. Journal of Economic Surveys, 25(1): 19-68. DOI 10.1111/j.1467-6419.2009.00602.x.

Rigby, R. A., and Stasinopoulos, D. M. (2005). Generalized additive models for location, scale and shape. Appl. Statist., 54(3): 507-554.

Stasinopoulos, M., Rigby, B., and Akantziliotou, C. (2008). Instructions on how to use the gamlss package in $R, 2$ edition.

Stephens, J. D., Rueschemeyer, D., and Stephens, E. H. (1992). Capitalist Development and Democracy. University of Chicago Press, 1 edition.

Treier, S., and Jackman, S. (2008). Democracy as a Latent Variable. American Journal of Political Science, 52(1): 201-217. 


\section{Appendix}

Table A1: Freedom House and Maddison GDP per capita

\begin{tabular}{|c|c|c|c|c|}
\hline $\begin{array}{c}\text { Dependent variable: } \\
\text { democracy }\end{array}$ & $\begin{array}{l}5 \text { year } \\
(\mathrm{M} 1)\end{array}$ & $\begin{array}{c}10 \text { year } \\
(\mathrm{M} 2)\end{array}$ & $\begin{array}{c}20 \text { year } \\
\text { (M3) }\end{array}$ & $\begin{array}{c}5 \text { year average } \\
\text { (M4) }\end{array}$ \\
\hline \multicolumn{5}{|l|}{ Mean equation $(\mu)$} \\
\hline Lag democracy & $\begin{array}{c}1.094 * * * \\
(1.673)\end{array}$ & $\begin{array}{c}-0.714 * * * \\
(0.261)\end{array}$ & $\begin{array}{c}-1.638^{* * * *} \\
(0.190)\end{array}$ & $\begin{array}{c}1.535 * * * \\
(0.186)\end{array}$ \\
\hline Lag log income per capita & $\begin{array}{c}-0.197 \\
(0.140)\end{array}$ & $\begin{array}{l}-0.305 \\
(0.271)\end{array}$ & $\begin{array}{l}0.326^{*} \\
(0.169)\end{array}$ & $\begin{array}{c}-0.330 * * \\
(0.149)\end{array}$ \\
\hline OECD (D) & $\begin{array}{l}2.529 * \\
(1.319)\end{array}$ & $\begin{array}{c}0.997 \\
(0.954)\end{array}$ & $\begin{array}{l}-0.432 \\
(0.661)\end{array}$ & $\begin{array}{c}4.424 * * * \\
(1.386)\end{array}$ \\
\hline Country fe & Yes & Yes & Yes & Yes \\
\hline Year fe & Yes & Yes & Yes & Yes \\
\hline \multicolumn{5}{|l|}{ Scale equation $(\sigma)$} \\
\hline Lag Democracy & $-* * *$ & + & No & - \\
\hline Lag Log income per capita & $+* * *$ & $+* * *$ & $+* * *$ & + \\
\hline OECD $(\mathrm{D})$ & $+* *$ & $+* * *$ & - & $+^{*}$ \\
\hline Country fe & No & No & No & No \\
\hline Year fe & No & No & No & No \\
\hline \multicolumn{5}{|l|}{ Zero inflation equation $(v)$} \\
\hline Lag democracy & $\begin{array}{l}-2.281 * * \\
(1.036)\end{array}$ & $\begin{array}{c}-3.295 * * * \\
(0.712)\end{array}$ & $\begin{array}{c}-3.453 * * \\
(1.333)\end{array}$ & $\begin{array}{c}-8.941 * * * \\
(1.104)\end{array}$ \\
\hline Lag log income per capita & $\begin{array}{l}-0.078 \\
(0.062)\end{array}$ & $\begin{array}{l}-0.068 \\
(0.091)\end{array}$ & $\begin{array}{c}0.195 \\
(0.167)\end{array}$ & $\begin{array}{l}-0.035 \\
(0.076)\end{array}$ \\
\hline OECD (D) & $\begin{array}{l}-2.281 \\
(1.036)\end{array}$ & $\begin{array}{c}-20.728 \\
(7.946 e+3)\end{array}$ & $\begin{array}{c}-19.281 \\
(5.256 \mathrm{e}+3)\end{array}$ & $\begin{array}{c}-16.993 \\
(1.588+\mathrm{e} 3)\end{array}$ \\
\hline Country fe & No & No & No & No \\
\hline Year fe & No & No & No & No \\
\hline \multicolumn{5}{|l|}{ One inflation equation $(\tau)$} \\
\hline Lag democracy & $\begin{array}{c}14.879 * * * \\
(1.827)\end{array}$ & $\begin{array}{c}7.170 * * * \\
(1.213)\end{array}$ & $\begin{array}{c}2.667 * * * \\
(0.838)\end{array}$ & $\begin{array}{c}21.498 * * * \\
(2.795)\end{array}$ \\
\hline Lag log income per capita & $\begin{array}{c}0.178 \\
(0.111)\end{array}$ & $\begin{array}{c}0.170 \\
(0.140)\end{array}$ & $\begin{array}{c}0.253 \\
(0.198)\end{array}$ & $\begin{array}{c}0.218 \\
(0.137)\end{array}$ \\
\hline OECD (D) & $\begin{array}{c}1.203 * * * \\
(0.373)\end{array}$ & $\begin{array}{c}1.740 * * * \\
(0.454)\end{array}$ & $\begin{array}{c}1.993 * * * \\
(0.566)\end{array}$ & $\begin{array}{l}0.844^{*} \\
(0.457)\end{array}$ \\
\hline Country fe & No & No & No & No \\
\hline Year fe & No & No & No & No \\
\hline Observation & 858 & 384 & 141 & 748 \\
\hline Country & 136 & 127 & 88 & 136 \\
\hline Global deviance & 187.998 & 109.918 & -79.631 & -165.615 \\
\hline AIC & 505.998 & 401.918 & 128.370 & 150.385 \\
\hline SBC & 1261.98 & 978.712 & 435.041 & 879.935 \\
\hline
\end{tabular}

The coefficients are in logit form for the equations for $\mu$ and $\sigma$, in $\log$ form for the equations for $v$ and $\tau$. The equation for $\sigma$ only shows the direction of relationship and its significance level. Significance levels are $0.1\left(^{*}\right)$, $\left.0.05{ }^{* *}\right)$ and $0.01(* * *)$. Standard errors are in parentheses with "qr" type, which assumes there is no correlation among the parameters. Models M1-M3 are estimated using 5, 10 and 20 year intervals, respectively. 
Table A2: Polity IV and Maddison GDP per capita

\begin{tabular}{|c|c|c|c|c|}
\hline $\begin{array}{c}\text { Dependent variable: } \\
\text { democracy }\end{array}$ & $\begin{array}{l}5 \text { year } \\
\text { (M1) }\end{array}$ & $\begin{array}{l}10 \text { year } \\
\text { (M2) }\end{array}$ & $\begin{array}{c}20 \text { year } \\
\text { (M3) }\end{array}$ & $\begin{array}{c}5 \text { year average } \\
\text { (M4) }\end{array}$ \\
\hline \multicolumn{5}{|l|}{ Mean equation $(\mu)$} \\
\hline Lag democracy & $\begin{array}{c}1.477 * * * \\
(0.177)\end{array}$ & $\begin{array}{l}-0.309 \\
(0.288)\end{array}$ & $\begin{array}{l}-2.253^{* * *} \\
(0.459)\end{array}$ & $\begin{array}{c}2.063 * * * \\
(0.181)\end{array}$ \\
\hline Lag log income per capita & $\begin{array}{c}0.102 \\
(0.152)\end{array}$ & $\begin{array}{c}0.146 \\
(0.271)\end{array}$ & $\begin{array}{l}-0.251 \\
(0.436)\end{array}$ & $\begin{array}{c}0.056 \\
(0.140)\end{array}$ \\
\hline OECD (D) & $\begin{array}{l}1.515^{* *} \\
(0.639)\end{array}$ & $\begin{array}{c}2.222 * * \\
(1.077)\end{array}$ & $\begin{array}{c}4.842 * * * \\
(1.258)\end{array}$ & $\begin{array}{c}1.715 * * * \\
(0.621)\end{array}$ \\
\hline Country fe & Yes & Yes & Yes & Yes \\
\hline Year fe & Yes & Yes & Yes & Yes \\
\hline \multicolumn{5}{|l|}{ Scale equation $(\sigma)$} \\
\hline Lag Democracy & + & $+* *$ & No & $-* * *$ \\
\hline Lag Income per capita & $+^{*}$ & + & $+* * *$ & + \\
\hline $\mathrm{OECD}(\mathrm{D})$ & - & $+* * *$ & $-* * *$ & + \\
\hline Country fe & No & No & No & No \\
\hline Year fe & No & No & No & No \\
\hline \multicolumn{5}{|l|}{ Zero inflation equation $(v)$} \\
\hline Lag democracy & $\begin{array}{c}-81.900 * * * \\
(12.818)\end{array}$ & $\begin{array}{c}-84.980 * * * \\
(23.682)\end{array}$ & $\begin{array}{c}-947.178 \\
(2.453 e+6)\end{array}$ & $\begin{array}{c}-113.832 * * * \\
(26.146)\end{array}$ \\
\hline Lag log income per capita & $\begin{array}{c}0.097 \\
(0.215)\end{array}$ & $\begin{array}{c}0.273 \\
(0.341)\end{array}$ & $\begin{array}{c}8.363^{* * *} \\
(1.109)\end{array}$ & $\begin{array}{c}0.360 \\
(0.300)\end{array}$ \\
\hline OECD (D) & $\begin{array}{c}-13.207 \\
(1.40 \mathrm{e}+3)\end{array}$ & $\begin{array}{c}-14.515 \\
(3.428 \mathrm{e}+3)\end{array}$ & $\begin{array}{c}14.040 \\
(1.014 \mathrm{e}+6)\end{array}$ & $\begin{array}{c}-13.039 \\
(3.637 \mathrm{e}+3)\end{array}$ \\
\hline Country fe & No & No & No & No \\
\hline Year fe & No & No & No & No \\
\hline \multicolumn{5}{|l|}{ One inflation equation $(\tau)$} \\
\hline Lag democracy & $\begin{array}{c}38.408 * * * \\
(5.146)\end{array}$ & $\begin{array}{c}9.567 * * * \\
(2.148)\end{array}$ & $\begin{array}{c}5.759 * * * \\
(1.226)\end{array}$ & $\begin{array}{c}40.592 * * * \\
(5.924)\end{array}$ \\
\hline Lag log income per capita & $\begin{array}{l}-0.229 \\
(0.144)\end{array}$ & $\begin{array}{l}-0.217 \\
(0.150)\end{array}$ & $\begin{array}{c}-0.556^{* *} \\
(0.280)\end{array}$ & $\begin{array}{l}-0.206 \\
(0.162)\end{array}$ \\
\hline OECD (D) & $\begin{array}{c}2.500 * * * \\
(0.533)\end{array}$ & $\begin{array}{c}2.936 * * * \\
(0.573)\end{array}$ & $\begin{array}{c}4.054 * * * \\
(1.012)\end{array}$ & $\begin{array}{l}2.503 * * * \\
(0.608)\end{array}$ \\
\hline Country fe & No & No & No & No \\
\hline Year fe & No & No & No & No \\
\hline Observation & 858 & 384 & 141 & 748 \\
\hline Country & 136 & 127 & 89 & 136 \\
\hline Global deviance & -629.735 & -211.350 & -230.628 & -760.734 \\
\hline AIC & 311.735 & 80.650 & -18.628 & -444.734 \\
\hline SBC & 444.248 & 657.444 & 293.941 & 284.816 \\
\hline
\end{tabular}

The coefficients are in logit form for the equations for $\mu$ and $\sigma$, in $\log$ form for the equations for $v$ and $\tau$. The equation for $\sigma$ only shows the direction of relationship and its significance level. Significance levels are $0.1(*)$, $0.05(* *)$ and $0.01(* * *)$. Standard errors are in parentheses with "qr" type, which assumes there is no correlation among the parameters. Models M1-M3 are estimated using 5, 10 and 20 year intervals, respectively. 
Table A3: Modeling the relationship between OECD membership history and democracy

\begin{tabular}{|c|c|c|c|c|c|c|}
\hline \multirow{2}{*}{$\begin{array}{c}\text { Dependent variable: } \\
\text { democracy }\end{array}$} & \multicolumn{2}{|c|}{5 year } & \multicolumn{2}{|c|}{10 year } & \multicolumn{2}{|c|}{5 year average } \\
\hline & (M1) & (M2) & (M3) & (M4) & (M5) & (M6) \\
\hline \multicolumn{7}{|l|}{ Mean equation $(\mu)$} \\
\hline Lag democracy & $\begin{array}{l}1.334 * * \\
(0.556)\end{array}$ & $\begin{array}{l}1.743^{* * * *} \\
(0.0 .497)\end{array}$ & $\begin{array}{c}-2.157 * * * \\
(0.608)\end{array}$ & $\begin{array}{c}0.004 \\
(0.781)\end{array}$ & $\begin{array}{c}2.931 * * * \\
(0.637)\end{array}$ & $\begin{array}{c}3.053^{* * *} * \\
(0.507)\end{array}$ \\
\hline \multirow[t]{2}{*}{ Lag log income per capita } & 0.353 & $1.251 * * *$ & $1.952 * * *$ & $1.443 * * *$ & -0.266 & $0.789 * * *$ \\
\hline & $(0.248)$ & $(0.264)$ & $(0.389)$ & $(0.415)$ & $(0.238)$ & $(0.255)$ \\
\hline Lag OECD (D) & $\begin{array}{c}-0.180 \\
(0.280)\end{array}$ & $\begin{array}{c}0.470 \\
(0.391)\end{array}$ & $\begin{array}{c}0.377 \\
(0.514)\end{array}$ & $\begin{array}{c}0.480 \\
(0.542)\end{array}$ & $\begin{array}{c}0.231 \\
(0.252)\end{array}$ & $\begin{array}{l}0.644^{*} \\
(0.354)\end{array}$ \\
\hline Country fe & Yes & Yes & Yes & Yes & Yes & Yes \\
\hline Year fe & No & No & No & No & Yes & Yes \\
\hline \multicolumn{7}{|l|}{ Scale equation $(\sigma)$} \\
\hline Lag democracy & -*** & -*** & - & - & $-* * *$ & $-* *$ \\
\hline Lag log income per capita & $-* * *$ & $-* * *$ & - & $-* * *$ & $-* * *$ & $-* * *$ \\
\hline Country fe & No & No & No & No & No & No \\
\hline Year fe & No & No & No & No & No & Yes \\
\hline \multicolumn{7}{|l|}{ One inflation equation $(\tau)$} \\
\hline Lag democracy & $\begin{array}{c}19.626^{* * *} \\
(3.823)\end{array}$ & $\begin{array}{l}21.867 * * * \\
(5.493)\end{array}$ & $\begin{array}{c}21.204 * * * \\
(7.382)\end{array}$ & $\begin{array}{l}7.194 * * \\
(3.136)\end{array}$ & $\begin{array}{c}24.125^{* * *} \\
(5.221)\end{array}$ & $\begin{array}{c}23.249 * * * \\
(5.915)\end{array}$ \\
\hline Lag log income per capita & $\begin{array}{l}2.819^{* * * *} \\
(0.804)\end{array}$ & $\begin{array}{c}1.755^{* * * *} \\
(0.641)\end{array}$ & $\begin{array}{c}4.171^{* * * *} \\
(1.473)\end{array}$ & $\begin{array}{c}2.710^{* * * *} \\
(0.944)\end{array}$ & $\begin{array}{c}3.220^{* * *} \\
(0.958)\end{array}$ & $\begin{array}{l}1.474 * * \\
(0.654)\end{array}$ \\
\hline Lag OECD (D) & $\begin{array}{l}1.145^{*} \\
(0.625)\end{array}$ & $\begin{array}{c}0.350 \\
(0.555)\end{array}$ & $\begin{array}{c}1.050 \\
(1.183)\end{array}$ & $\begin{array}{l}-0.239 \\
(0.812)\end{array}$ & $\begin{array}{l}1.156 \\
(0.705)\end{array}$ & $\begin{array}{c}0.299 \\
(0.591)\end{array}$ \\
\hline Country fe & No & No & No & No & No & No \\
\hline Year fe & No & No & No & No & No & No \\
\hline Observation & 216 & 216 & 109 & 109 & 190 & 190 \\
\hline Country & 28 & 28 & 28 & 28 & 28 & 28 \\
\hline Global deviance & 2.914 & 1.174 & -12.468 & 6.228 & -41.169 & -32.020 \\
\hline AIC & 82.914 & 81.174 & 65.532 & 84.228 & 38.831 & 47.980 \\
\hline SBC & 217.925 & 216.814 & 170.495 & 189.191 & 168.712 & 177.861 \\
\hline
\end{tabular}

The coefficients are in logit form for the equations for $\mu$ and $\sigma$, in $\log$ form for the equations for $v$ and $\tau$. The equation for $\sigma$ only shows the direction of relationship and its significance level. Significance levels are $0.1(*)$, $0.05(* *)$ and $0.01(* * *)$. Standard errors are in parentheses with "qr" type, which assumes there is no correlation among the parameters. Country fixed-effects and year fixed-effects are used only when the algorithms converge. Models with odds number use Freedom House variable, models with even numbers use Polity 4 variable. The income variable for all models is from Penn World Table. 
Table A4: The original level of lag log income and probabilities of complete democracy in 2000

\begin{tabular}{ccccc}
\hline & \multicolumn{2}{c}{ India } & \multicolumn{2}{c}{ Brazil } \\
& Lag log income & Probability & Lag log income & Probability \\
\hline Five year & 8.201 & $1.575 \mathrm{e}-06$ & 8.819 & 0.339 \\
Ten year & 7.955 & $1.460 \mathrm{e}-03$ & 8.735 & 0.482 \\
Twenty year & 7.547 & $4.061 \mathrm{e}-03$ & 8.761 & 0.422 \\
Five year average & 8.218 & $5.941 \mathrm{e}-08$ & 8.833 & 0.054 \\
\hline Predictions use data source from Penn World Table and Freedom House.
\end{tabular}

Predictions use data source from Penn World Table and Freedom House.

Table A5: Predicted probabilities for complete democracy in India in 2000 Income percentile

\begin{tabular}{ccccc}
\hline & Five year & Ten year & Twenty year & Five year average \\
$80 \%$ & $4.999 \mathrm{e}-05$ & 0.179 & 0.865 & $2.328 \mathrm{e}-06$ \\
$90 \%$ & $1.778 \mathrm{e}-04$ & 0.498 & 0.973 & $9.195 \mathrm{e}-06$ \\
$100 \%$ & $1.230 \mathrm{e}-03$ & 0.910 & 0.980 & $7.507 \mathrm{e}-05$
\end{tabular}

Income percentiles are extracted from Penn World Table 1960-2000 and predicted probabilites of democracy is using Freedom House.

Table A6: Predicted probabilities for complete democracy in Brazil in 2000

\begin{tabular}{ccccc}
\hline Income percentile & \multicolumn{5}{c}{} \\
\hline & Five year & Ten year & Twenty year & Five year average \\
$80 \%$ & 0.699 & 0.889 & 0.886 & 0.224 \\
$90 \%$ & 0.888 & 0.973 & 0.977 & 0.525 \\
$100 \%$ & 0.981 & 0.997 & 0.998 & 0.897
\end{tabular}

Income percentiles are extracted from Penn World Table 1960-2000 and predicted probabilites of democracy is using Freedom House. 
Table A7: List of countries in Figure 5

\begin{tabular}{|c|c|c|c|c|c|c|c|}
\hline No. & Contry & No. & Country & No. & Country & No. & Country \\
\hline 1 & Angola* & 41 & Finland & 81 & Mexico & 121 & Syrian Arab Republic \\
\hline 2 & Albania & 42 & Fiji** & 82 & Mali & 122 & Chad \\
\hline 3 & United Arab Emirates* & 43 & France & 83 & Myanmar* & 123 & Togo \\
\hline 4 & Argentina & 44 & Gabon & 84 & Mongolia* & 124 & Thailand \\
\hline 5 & Australia & 45 & United Kingdom & 85 & Mozambique & 125 & Trinidad and Tobago \\
\hline 6 & Austria & 46 & Ghana & 86 & Mauritania & 126 & Tunisia \\
\hline 7 & Burundi & 47 & Guinea & 87 & Mauritius & 127 & Turkey \\
\hline 8 & Belgium & 48 & Gambia, The & 88 & Malawi & 128 & Taiwan \\
\hline 9 & Benin & 49 & Guinea-Bissau & 89 & Malaysia & 129 & Tanzania \\
\hline 10 & Burkina Faso & 50 & Equatorial Guinea & 90 & Namibia* & 130 & Uganda \\
\hline 11 & Bangladesh & 51 & Greece & 91 & Niger & 131 & Uruguay \\
\hline 12 & Bulgaria & 52 & Guatemala & 92 & Nigeria & 132 & United States \\
\hline 13 & Bahrain* & 53 & Guyana** & 93 & Nicaragua & 133 & USSR* \\
\hline 14 & Bolivia & 54 & Honduras & 94 & Netherlands & 134 & Venezuela, RB \\
\hline 15 & Brazil & 55 & Haiti & 95 & Norway & 135 & Vietnam \\
\hline 16 & Botswana & 56 & Hungary & 96 & Nepal & 136 & Yemen \\
\hline 17 & Central African Republic & 57 & Indonesia & 97 & New Zealand & 137 & South Africa \\
\hline 18 & Canada & 58 & India & 98 & Oman* & 138 & Congo, Dem. Rep. \\
\hline 19 & Switzerland & 59 & Ireland & 99 & Pakistan-post-1972 & 139 & Zambia \\
\hline 20 & Chile & 60 & Iran & 100 & Panama & 140 & Zimbabwe* \\
\hline 21 & China & 61 & Iraq* $^{*}$ & 101 & Peru & & \\
\hline 22 & Cote d'Ivoire & 62 & Iceland $* *$ & 102 & Philippines & & \\
\hline 23 & Cameroon & 63 & Israel & 103 & Papua New Guinea** & & \\
\hline 24 & Congo, Rep. & 64 & Italy & 104 & Poland & & \\
\hline 25 & Colombia & 65 & Jamaica & 105 & Korea, Dem. Rep.* & & \\
\hline 26 & Comoros & 66 & Jordan & 106 & Portugal & & \\
\hline 27 & Costa Rica & 67 & Japan & 107 & Paraguay & & \\
\hline 28 & Cuba & 68 & Kenya & 108 & Qatar* & & \\
\hline 29 & Cyprus** & 69 & Cambodia & 109 & Romania & & \\
\hline 30 & Czechoslovakia* & 70 & Korea, Rep. & 110 & Russia & & \\
\hline 31 & Germany & 71 & Kuwait* & 111 & Rwanda & & \\
\hline 32 & Djibouti* & 72 & Lao PDR* & 112 & Saudi Arabia* & & \\
\hline 33 & Denmark & 73 & Liberia* & 113 & Sudan* & & \\
\hline 34 & Dominican Republic & 74 & Libya* & 114 & Senegal & & \\
\hline 35 & Algeria & 75 & Sri Lanka & 115 & Singapore & & \\
\hline 36 & Ecuador & 76 & Lesotho & 116 & Sierra Leone & & \\
\hline 37 & Egypt, Arab Rep. & 77 & Lithuania & 117 & El Savador & & \\
\hline 38 & Spain & 78 & Latvia & 118 & Somalia* & & \\
\hline 39 & Estonia & 79 & Morocco & 119 & Sweden & & \\
\hline 40 & Ethiopia pre-1993 & 80 & Madagascar & 120 & Swaziland* & & \\
\hline
\end{tabular}

(*) excluded from Penn World Table; (**) excluded from Maddison GDP. 